\title{
Remote Surface Modification of Plastic by Atmospheric Barrier Discharge
}

\author{
Yuta Yanagisawa Student Member (Kanazawa Institue of Technology, everything_is_made_from_dream@yahoo.co.jp) \\ Yoshio Yoshioka Life Member (Kanazawa Institute of Technology, yoshioka@neptune.kanazawa-it.ac.jp)
}

Keywords : atmospheric barrier discharge, remote surface modification, plastic, contact angle, nitrogen barrier discharge

This paper shows investigation result of the improvement method of remote surface modification of plastic materials. The reforming effect at the points away from the discharge device is important in remote surface modification. Therefore, using a experimental setup shown in Fig.1, the contact angle of water was measured at a various points away from discharge device, and reforming effect was evaluated by the change of contact angle.

Three gases, namely air, nitrogen, and oxygen were used to investigate the effect of gas component. The aim of this experiment is mainly to know the effect of nitrogen radicals and the nitrogen excitation molecules, because it is expected that larger life time of nitrogen radicals and exited molecules improves the surface reforming at long distance from the discharge device. The relation between distance and the contact angle is shown in Fig.2. It is seen that in case of nitrogen, the contact angle is low even at $100 \mathrm{~mm}$, and moreover, the contact angles at the points from $10 \mathrm{~mm}$ to $30 \mathrm{~mm}$ are lower than that of the direct processing. On the other hand, in case of oxygen and air, the contact angle did not become small in remote reforming area. Thus it is understood that the use of nitrogen is very effective in remote plasma method.

Figure 3 shows results of experiments that keeping the discharge energy constant and changing processing time and discharge power, the contact angles were changed. It is understood that the processing time has a big influence on the reforming

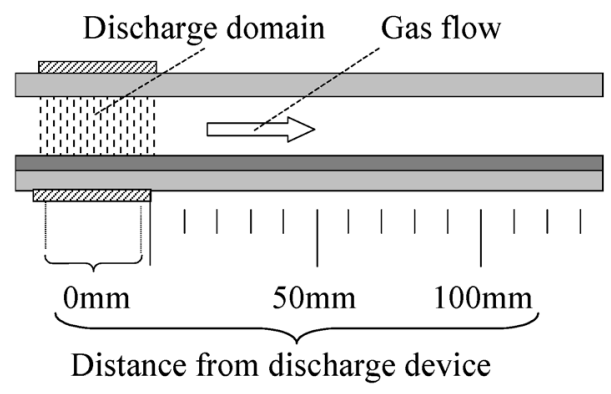

Fig. 1. Contact angle measurement point

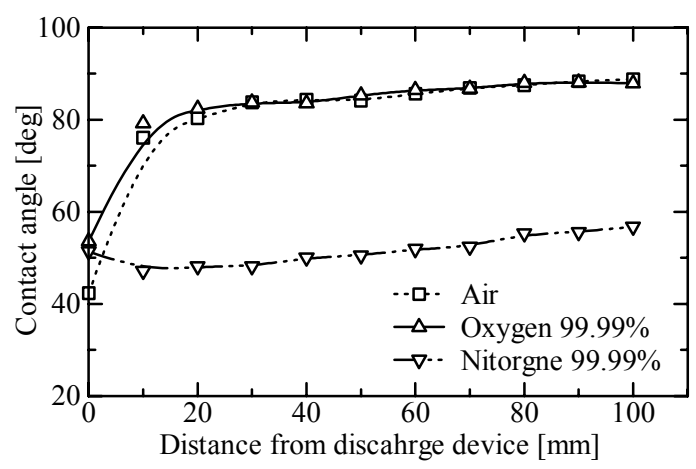

Fig. 2. Gas component vs. contact angle performance than discharge power. Therefore, discharge power is not a decisive factor in the remote processing method. Although figure is not shown, the gas flow speed is also very sensitive to the reforming performance, and high gas speed flow is effective to process longer distance from discharge device.

The surface reforming effect changed greatly by gas component. However, it cannot be asserted whether this excellent surface reforming effect is achieved in every plastic materials or not. Therefore, the surface reforming experiments of plastic other than PE were carried out using nitrogen plasma. The prepared materials were PP (polypropylene), PET (polyethylene Terephthalate), PVC (polyvinyl chloride), and PVDC (polyvinylidene chloride). The contact angles on those materials are shown in Fig.4. And, an initial contact angle of each plastic is shown in Table.1. It is found that nitrogen plasma is effective for all plastics tested. Therefore, it is expected that remote surface reforming by the nitrogen plasma is applicable to many other plastic materials.

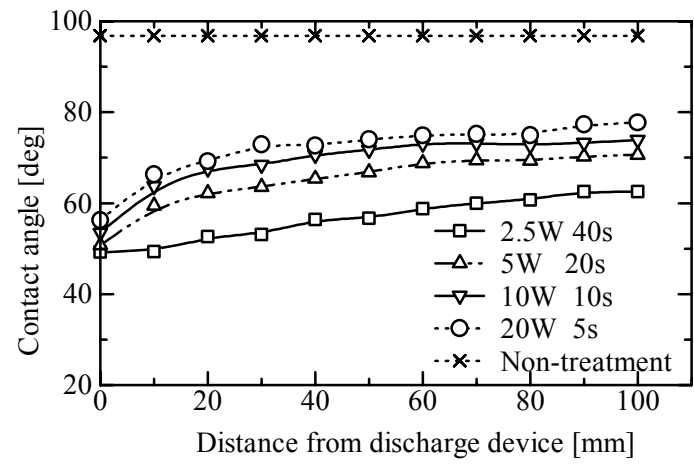

Fig. 3. Effect of discharge power and treatment time

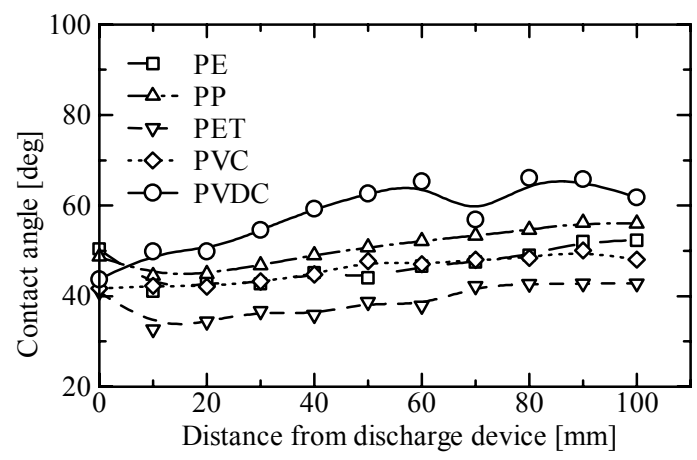

Fig. 4. Effect of discharge power and treatment time

Table 1. Initial contact angle

\begin{tabular}{|c|c|c|c|c|}
\hline PE & PP & PET & PVC & PVDC \\
\hline 96.8 & 99.2 & 82.9 & 88.9 & 79.2 \\
\hline
\end{tabular}




\begin{abstract}
大気圧バリア放電によるプラスチックのリモート表面改質 学生員 柳沢 雄太* 終身会員 吉岡 芳夫*

\author{
Remote Surface Modification of Plastics by Atmospheric Barrier Discharge
}

Yuta Yanagisawa*, Student Member, Yoshio Yoshioka*, Life Member

The surface modification by atmospheric pressure barrier discharge is effective in the improvement of adhesion performance of plastics. The remote plasma processing has several advantages against the direct plasma processing. They are free from the problem of surface damage and the charge accumulation and have larger freedom of setup of the system. However, it is necessary to improve the processing performances such as range of remote processing distance, reduction of contact angle and so on.

In this paper, we have investigated processing performances of the remote surface reforming. We used polyethylene film as the reforming object. It was found that the followings are very effective as processing condition; (1) use of nitrogen gas, (2) high speed gas flow and, (3) longer processing time.
\end{abstract}

論 文

キーワード : 大気圧バリア放電, リモート表面改質, プラスチック，接触角，窒素バリア放電

Keywords : atmospheric barrier discharge, remote surface modification, plastic, contact angle, nitrogen barrier discharge

\section{1. はじめに}

近年，プラスチックなどの高分子材料に対するプラズマ 表面改質の研究が盛んに行われている。プラスチックには 工業的に多数の優れた特徵がある半面, 接着性や印刷性に 難があるため, 必要に応じて表面処理を施し, 表面性質を 改善することが望まれている。これまでの表面改質技術の 主流は薬剤によるウェット処理であった。しかし，処理の 過程で用いる有機溶剂による環境污染問題がクローズアッ プされ, 次第に環境への影響の少ないプラズマ表面改質（溶 剂を使用しないためウェット処理に対し，ドライ処理とも 呼ばれる）へと移行してきた。

プラズマ表面改質では放電の発生や放電状態の保持の面 から減圧プラズマ処理を用いることが多い。しかしこの方 法では減圧設備のコストやランニングコストが高くなる 点, 或いは設備面積が広くなる点が問題である。そのため, 本研究では大気圧放電が可能な誘電体バリア放電 (DBD) による表面改質を検討している。この大気圧バリア放電は 高周波電源を用いることにより, 放電電力を大きくするこ とが出来る点で, 直流コロナ放電より有利である。

バリア放電による表面改質には直接プラズマ処理法とリ モートプラズマ処理法の二つの処理法がある。直接プラズ マ処理法とは試料を放電空間に直接配置する方法で, 処理 性能に優れるものの放電空間を飛び交う電子の衝突による

\footnotetext{
金沢工業大学

干921-8501 石川県石川郡野々市町扇が丘 7-1

Kanazawa Institute of Technology

7-1, Oogigaoka, Nonoichi-machi, Ishikawag-gun, Ishikawa $921-8501$
}

試料表面の損傷や電荷蓄積などが問題となる。リモートプ ラズマ処理法は試料を放電装置から離れた場所に置き, 放 電空間で発生した活性種を輸送して試料に吹き付けて表面 改質する方法である。この方法では直接プラズマ処理法の 問題の回避や, 放電部と処理部を大きく離すことで安全性 向上が見込めるが，距離が大きくなると処理性能が悪くな る問題がある。我々は試料保護や安全性向上の観点からリ モートプラズマ処理法を研究することとした。

本論文では大気圧バリア放電を用いたプラスチックのリ モート表面改質法の処理性能向上, 処理範囲拡大を目的に 検討を進めた。この結果, 雰囲気ガスとして窒素ガスの使 用がリモート表面改質距離拡大や処理性能向上に特に有効 であることや, 放電電力や処理時間の変化も処理性能に影 響の大きなパラメータであることが分かった。また，今回 明らかになったリモート表面改質特性が多くのプラスチッ ク材料で得られることを確認した。これらの結果について 以下記述する。なお, 本論文では表面改質効果の評価に水 の接触角の変化を用いた。

\section{2. 実験装置および実験システム}

〈2·1〉リモートプラズマ処理装置本研究で用いた リモートプラズマ処理装置の概略図を図 1 に示す。電極構 成を両バリア構造, ガスギャップ長を試料が挿入された状 態で $2 \mathrm{~mm}$ とした。装置材質として, 電極にアルミテープ, 試料を貼り付けるカートリッジとバリア層に $3 \mathrm{~mm}$ 厚のソー ダガラス, ギャップを保つためのスペーサにはアクリルを 使用した。改質物には, 主にポリエチレンフィルムを使用 した。 
本装置では，放電に伴い発生するラジカルなどの活性種 をガス流により電極外に輸送し，電極から離れた場所で試 料の表面改質に利用している。改質物の挿入法として, カ ートリッジに貼り付けた改質物を装置内下部に挿入する方 法を採用した。この方法を採用することで, 電極間内部で は直接プラズマ処理効果を, 電極間外側のガス下流部では リモートプラズマ処理効果を同時に得ることが出来る。ま た，図 2 に示すように電極端から $10 \mathrm{~mm}$ 間隔で水の接触角 を測定していく事で, 電極からの距離と表面改質効果の関 係を明らかにすることが可能となる。この場合には，電極 内部の直接表面改質領域を $0 \mathrm{~mm}$ として扱った。

〈2·2〉 実験システム＼cjkstart実験システムの構成を図 3 に 示す。メモリハイコーダ（HIOKI Model 8807）の演算機能で 算出された V-Q リサージュ面積により, 放電電力を求めた。 また，放電装置内部に流入させるガス流量をフローメータ で測定した。使用した酸素ボンベ, 窒素ボンベのガス純度

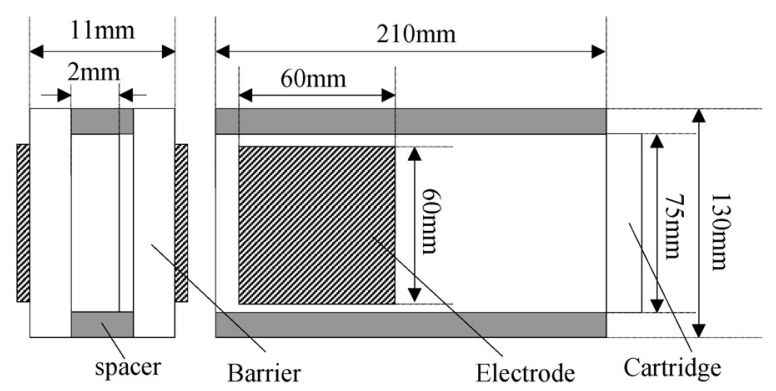

図 1 リモートプラズマ処理装置

Fig. 1. Remote plasma processing device.

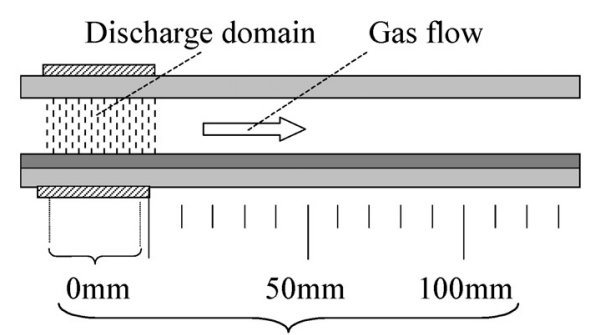

Distance from discharge device

図 2 接触角測定箇所

Fig. 2. Contact angle measurement point.

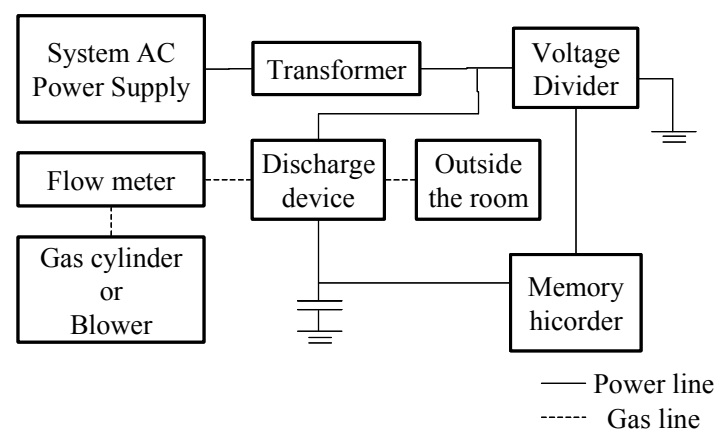

図 3 実験システム

Fig. 3. Experimental system.
はそれぞれ 99.99\%である。ガスボンベからリモートプラズ マ処理装置出口付近までガスの漏れの無いように製作した ため, ガス流速 $[\mathrm{m} / \mathrm{s}]$ はガス流量 $\left[\mathrm{m}^{3} / \mathrm{h}\right]$ を装置内部断面積 $\left[\mathrm{m}^{2}\right]$ で割り算することにより求めることが出来る。本実験のガ ス流速の調節範囲は $5 \mathrm{~m} / \mathrm{s}$ から $30 \mathrm{~m} / \mathrm{s}$ の範囲である。

\section{3. 放電処理条件の影響}

〈3·1〉リモート表面改質効果 まず，製作したリモ 一ト表面改質装置の基礎処理特性を調べた。その結果を図 4 に示す。処理条件を放電電力 $5 \mathrm{~W}$, 周波数 $600 \mathrm{~Hz}$, 処理時間 $60 \mathrm{~s}$, 雰囲気ガスを空気, ガス流速を $5 \mathrm{~m} / \mathrm{s}$ とした。

図 4 を見ると, 直接表面改質領域（ $0 \mathrm{~mm}$ 地点）では水の 接触角が大幅に低下し，優れた表面改質効果が得られてい ることが分かる。一方, リモート表面改質領域（10mm〜 $100 \mathrm{~mm}$ 地点）でも接触角は未処理時の 96 度から 80 度程度 にまで減少し，ある程度の表面改質効果が得られているが， 直接表面改質領域と比べると大幅に劣ることが分かる。

このように, リモート表面改質では直接表面改質と同程 度の処理効果を得ることが難しい。そこでまずはこのリモ 一ト表面改質法において, 周波数, 放電電力, ガス流速, 処理時間を変化させた場合と, 雰囲気ガスを変えた場合の 違いを調へ，処理性能向上に有効なパラメータを明らかに する。それらの結果を以下に示していく。

〈3·2〉 周波数の影響一般に, 放電により発生する 酸素ラジカルなどの活性種の量は放電電力量に依存する。 従って, 一定放電電力量の下であれば, 周波数を変化させ ても活性種の発生量は変わらず, リモート表面改質効果に 違いはないと予想される。実際に実験を行い, この影響を 調べた。

図 5 に周波数の違いによるリモート改質効果の変化を示 す。処理条件を放電電力 $5 \mathrm{~W}$, 処理時間 $60 \mathrm{~s}$, ガス流速 $5 \mathrm{~m} / \mathrm{s}$, 雰囲気ガスを空気, 周波数を $200,400,600,800[\mathrm{~Hz}]$ とし た。

この結果を見ると, 放電電力量を同じにすれば周波数の 違いによる接触角の違いは殆んどない。従って, 実験前の 予想通り周波数の違いによる影響はないと言える。

〈3・3〉放電電力の影響 活性種の生成量が放電電力

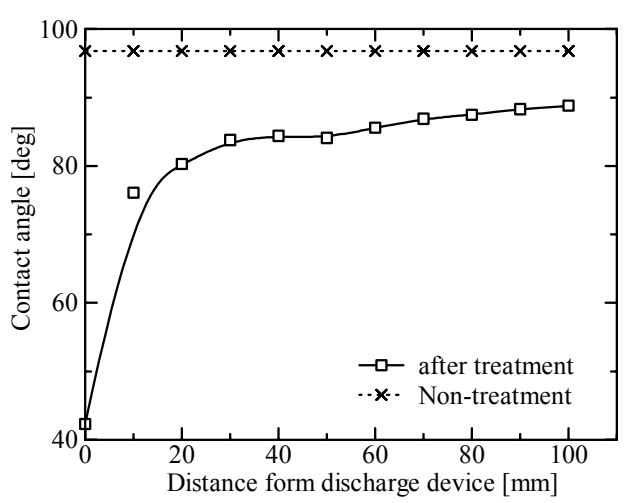

図 4 基礎処理特性

Fig. 4. Basic treatment characteristic. 


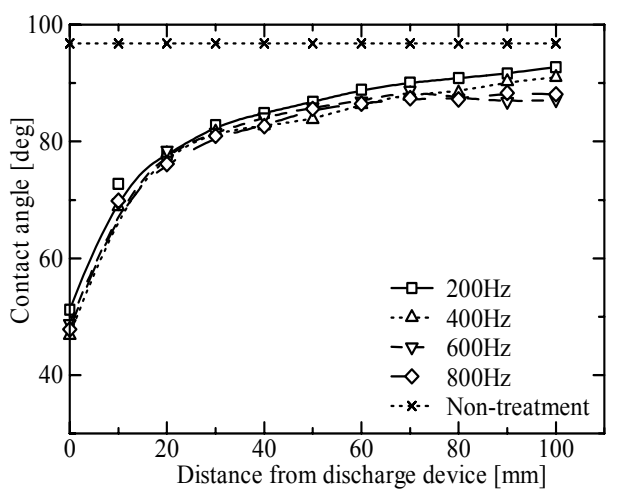

図 5 周波数の違いによるリモート表面改質効果の変化

Fig. 5. Frequency vs. contact angle in air.

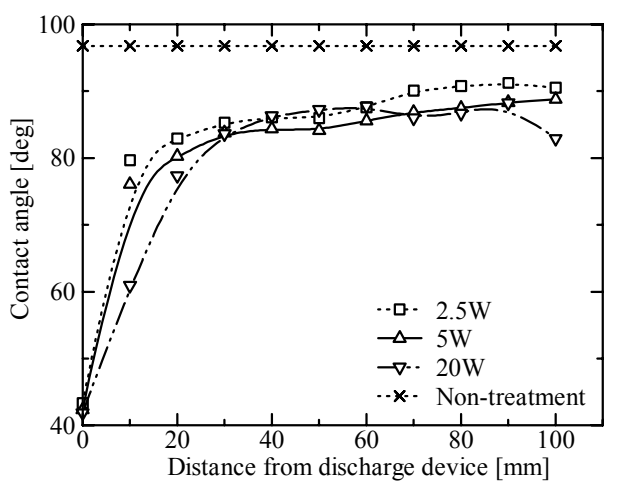

図 6 放電電力の違いによるリモート表面改質効果の変化

Fig. 6. Discharge power vs. contact angle in air.

に依存して変化することは既に述べた。つまり，放電電力 を大きく寸れば，活性種の発生量が増加し，その効果によ りリモート表面改質効果が向上寸ると考えられる。そこで, 放電電力が改質効果に与える影響を調べた。

図 6 に放電電力の違いによるリモート表面改質効果の変 化を示す。処理条件を，処理時間 $60 \mathrm{~s}$, ガス流速 $5 \mathrm{~m} / \mathrm{s}$, 周波 数 $600 \mathrm{~Hz}$, 雾囲気ガスを空気, 放電電力を $2.5,5,20[\mathrm{~W}]$ と した。

この結果を見ると, 電極から近い領域では放電電力の増 加に伴い表面改質効果が向上していることが分かる。しか し, 電極内及び電極から遠い領域では放電電力変化に伴う 表面改質効果の変化は僅かであった。

このような実験結果が出たのは, ラジカルの量と種類が 3 つの領域で変化したためではないかと考えている。この 3 つの領域とは, (1) 酸素ラジカルが主体で試料表面に作用し ている領域 $(0 \mathrm{~mm}$ 地点), (2) ガス雰囲気中の酸素ラジカル が減少し, オゾンが増えていくことにより, 試料表面に作 用する酸素ラジカル量が著しく減少していく領域 (0mm<20mm 区間)，(3) ガス中の酸素ラジカルがなくなり, オゾンのみが試料表面に作用する領域 $(20 \mathrm{~mm}$ よりも離れた 領域), である。

このうち, (1)の領域では, $2.5 \mathrm{~W}$ の放電電力でも酸素ラジ カルが十分存在するので, PE は飽和するまで改質され，そ れ以上電力を増やしても効果は向上しない。(2)の領域では,
酸素ラジカルが急激に減少し，オゾンが増えていく。この 場合は，PE を十分に改質させることはできないが，放電電 力を大きくすれば残留する酸素ラジカルが多くなるので放 電電力の影響が現れる。そして, (3)の領域では, 寿命の短 い酸素ラジカルは完全に無くなって，オゾンに変わる。そ して, オゾンの量は $2.5 \mathrm{~W}$ の放電電力でもオゾンが表面改質 できる十分な量となっているので, それ以上放電電力を増 やしても, オン゙ンによる表面改質の限界までしか改質は進 まない。

したがって, リモート表面改質の距離を拡大寸るために はラジカル寿命に着目寸る必要がある。例えば, より寿命 の長い活性種を用いたり, 短い時間でラジカルを遠くまで 輸送したりするなどのアプローチが有効であると予想され る。

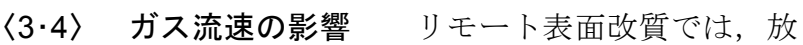
電により発生した寿命の短い活性種をガス流によって電極 外へ輸送するため, 短い時間でより遠くまで運ぶことが必 要であることは既に述べた。つまり，ガス流速を早くする ことで改質出来る距離や表面改質効果が向上寸ると考えら れる。そこで，ガス流速がリモート表面改質効果に与える 影響を調べた。

図 7 にガス流速の違いによるリモート表面改質効果の変 化を示寸。処理条件を放電電力 $5 \mathrm{~W}$, 周波数 $600 \mathrm{~Hz}$, 処理時 間 $60 \mathrm{~s}$ ，雰囲気ガスを空気，ガス流速を $5 ， 10 ， 20[\mathrm{~m} / \mathrm{s}]$ とし た。

この結果を見ると，ガス流速を増加させるとリモート表 面改質効果が向上していることが分かる。例えば，電極か ら $50 \mathrm{~mm}$ 離れた地点に注目寸ると, 接触角は約 80 度から 65 度程度にまで低下している。〈3・3 節の実験結果から, オ ゾンになどによる作用だけでここまで接触角が低下寸ると は考えにくい。つまり，この様に接触角が低下したのは， 流速が速くなることで酸素ラジカルの到達する距離が伸び たためだと考えられる。

〈3.5〉処理時間の影響表面改質効果は処理時間を 長くすることで向上すると考えられる。特に，処理時間の 影響は，これまでに調べた放電電力やガス流速と比べると 最も大きいと予想される。すなわち，処理時間を倍にする と改質物に到達する活性種の量はほぼ倍になると考えられ るからである。そこで，処理時間を短くした場合や長くし た場合に表面改質効果にどのような影響を与えるかを調心゙ た。

図 8 に処理時間によるリモート改質効果の変化を示す。 処理条件を, ガス流速 $5 \mathrm{~m} / \mathrm{s}$, 放電電力 $5 \mathrm{~W}$, 周波数 $600 \mathrm{~Hz}$, 雰囲気ガス空気，処理時間を $5,10 ， 30 ， 60 ， 120[\mathrm{~s}]$ と変化 させた。

この結果を見ると, リモート表面改質領域では, 処理時 間を長くしていくことで表面改質効果が高まっていくこと が分かる。そして, 処理時間 60s 120s で改質効果の改良度 合いが小さくなっているため, 処理時間 120s ではオゾンに よる改質限度付近まで改質されていると考えられる。 


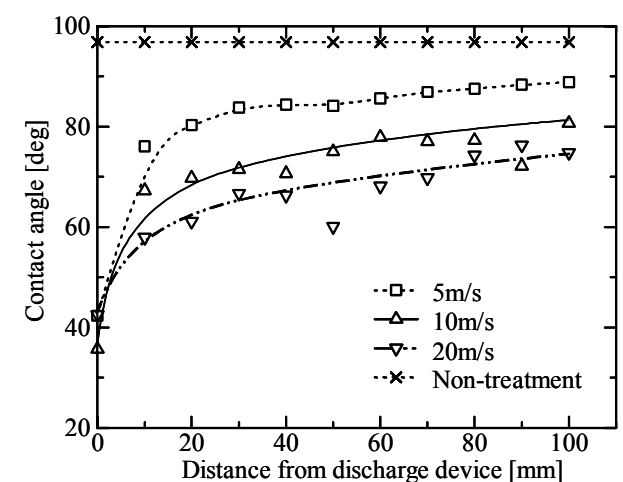

図 7 ガス流速の違いによるリモート表面改質効果の変化

Fig. 7. Gas flow rate vs. contact angle in air.

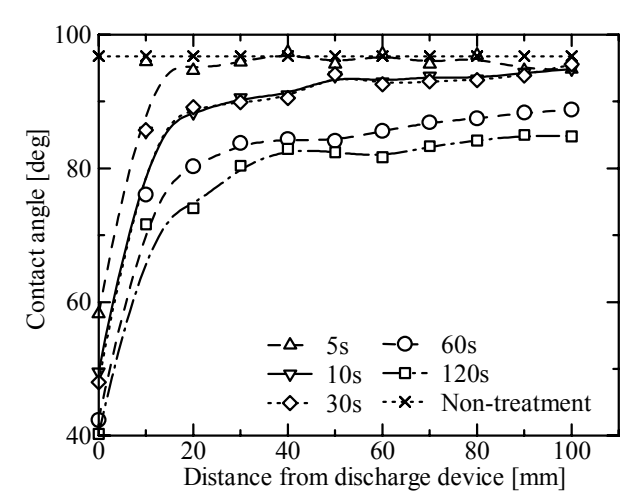

図 8 処理時間のちがいによるリモート表面 改質効果の変化

Fig. 8. Treatment time vs. contact angle in air.

一方, 直接放電処理領域内では僅か $5 \mathrm{~s}$ の処理でも十分な 表面改質効果が得られており, 処理時間を $60 \mathrm{~s}$ と長くしても 更なる表面改質効果は認められない。これも, 酸素ラジカ ルによる表面改質効果が $5 \mathrm{~s}$ で既に飽和しているためだと考 えられる。

〈3.6〉雾囲気ガスの变化酸素中放電や空気中放電 を利用したPEの表面改質では, 酸素ラジカルが表面を改質 する(1)。しかし, 酸素ラジカルは平均寿命が $10^{-5}$ 秒とごく短 時間で消失してしまうため, リモート表面改質の遠距離化 に適していない。そこでリモート表面改質に窒素ラジカル や窒素励起分子の適用を試みた。これらのうち，特に窒素 励起分子は長寿命であることが知られている。また，ポテ ンシャルエネルギーも約 $8 \mathrm{eV}$ で酸素ラジカルの約 $5.5 \mathrm{eV}$ よ り高いため, リモート表面改質効果向上が期待できる。リ モート表面改質効果の比較のため, ここでは酸素ガス, 室 内空気，そして窒素ガスを用いたリモート表面改質実験を 行った。

図 9 にガス種類によるリモート表面改質効果の違いを示 す。処理条件を放電電力 $5 \mathrm{~W}$, 周波数 $600 \mathrm{~Hz}$, 処理時間 $60 \mathrm{~s}$, ガス流速 $5 \mathrm{~m} / \mathrm{s}$, 雰囲気ガスを窒素, 空気, 酸素とした。

この実験結果を見ると, 雰囲気ガスに窒素を用いても PE の接触角を低下させることができている。これは，窒素励 起分子の反応や, 窒素励起分子の衝突により放出された水

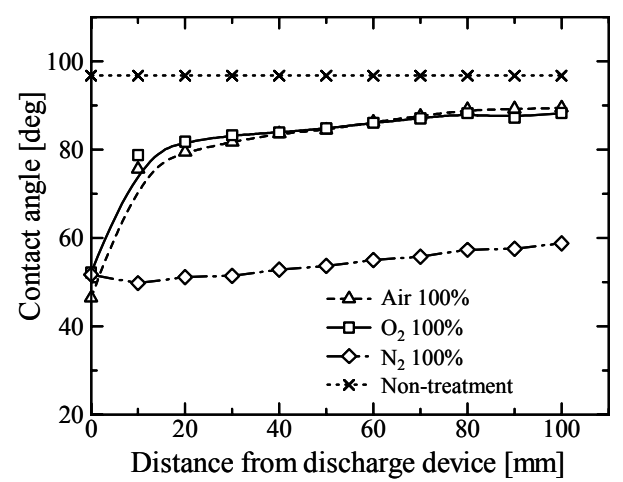

図 9 ガスの種類によるリモート表面改質効果の変化

Fig. 9. Contact angle vs. gas component.

素ラジカルの再反応により, PE 表面に親水性官能基の一つ であるアミド基（N-H2）が形成されたためであると考えら れる。また, 窒素励起分子の長寿命という特徵により, 放 電装置から $100 \mathrm{~mm}$ 離れた地点でも優れた表面改質効果が得 られ, また, 電極に近い領域では直接処理効果を上回る処 理効果が得られている。

これらの結果から, リモート表面改質距離の拡大や表面 改質効果向上に窒素ガスの使用が非常に有効であることが 分かった。また, 窒素を多量に含んでいる空気と純酸素を 使ったときのリモート表面改質距離にほとんど違い現れな かったことも興味深い。これは, 酸素ラジカルと窒素分子, 窒素ラジカルなどがガス雾囲気内で結合し, 窒素酸化物 （NOX）に変化すること, 窒素の存在でオゾン生成が促進さ れ, 酸素ラジカルの減衰が速いことが原因だと考えられる。

しかし，この実験では窒素処理の有効性が確認できた。 そこで, 次章では窒素ガスによるリモート表面改質（以降 窒素処理と呼ぶ）における処理条件の影響を調べて行くこ とにする。

\section{4. 窒素処理における放電処理条件の影響}

〈4·1〉 ガス流速の影響 図 10 に窒素処理におけるガ ス流速の影響を調べた結果を示す。処理条件を放電電力 $5 \mathrm{~W}$, 処理時間 $60 \mathrm{~s}$, 周波数 $600 \mathrm{~Hz}$, ガス流速を $5,10,20[\mathrm{~m} / \mathrm{s}]$ とした。

この結果を見ると, 窒素処理では電極から離れた地点で 僅かにガス流速変化の影響が見られるものの, 最小の $5 \mathrm{~m} / \mathrm{s}$ でもリモート表面改質が行われており，空気処理のときの ような流速依存性は無いことが分かる。これは窒素ラジカ ルの寿命が長く, 流速 $5 \mathrm{~m} / \mathrm{s}$ でも距離 $100 \mathrm{~mm}$ までラジカル が存在するためであると考えられる。この実験では装置の 都合で電極からの距離が $100 \mathrm{~mm}$ より離れた地点の表面改質 効果を調べることが出来なかった。100mm よりも更に離れ た地点ではガス流速の変化の影響が現れると推測される。

〈4·2〉放電電力の影響図 11 に窒素処理における放 電電力の影響を調べた結果を示す。処理条件を処理時間 $60 \mathrm{~s}$ ，ガス流速 $5 \mathrm{~m} / \mathrm{s}$, 放電電力を $2.5,5,20[\mathrm{~W}]$ とした。

この結果を見ると, 空気処理の時と異なり放電電力を増 


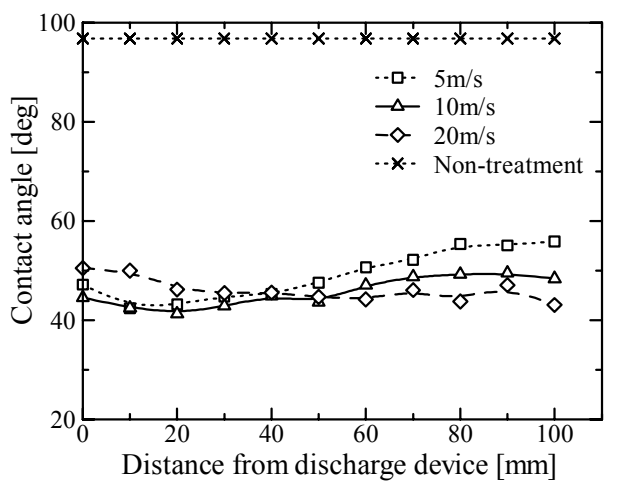

図 10 ガス流速の違いによるリモート表面改質効果の変化

Fig. 10. Gas flow rate vs. contact angle in nitrogen.

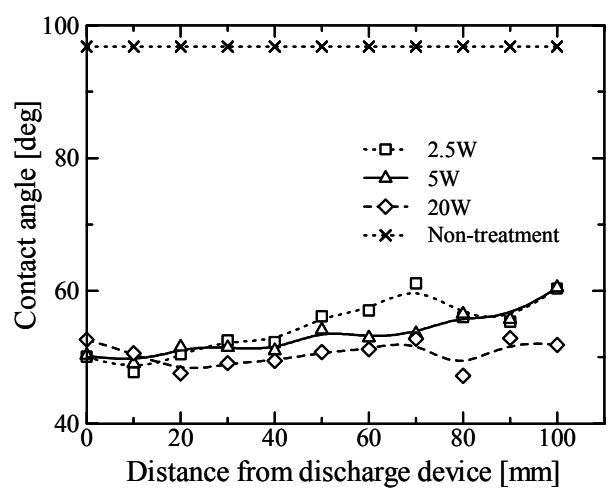

図 11 放電電力の違いによるリモート表面改質効果の変化

Fig. 11. Discharge power vs. contact angle in nitroge.

加させてもリモート表面改質効果はあまり向上していな い。しかし, 電極からの距離の遠い地点では放電電力の増 加に共に伴い，僅かに表面改質効果が向上していることが 分かる。

〈4·3〉処理時間の影響図 12 に窒素処理における処 理時間と表面改質効果の関係を調べた結果を示す。処理条 件を, 放電電力 $5 \mathrm{~W}$, 周波数 $600 \mathrm{~Hz}$, ガス流速 $5 \mathrm{~m} / \mathrm{s}$, 処理時 間を $5 ， 10 ， 30 ， 60 ， 120[\mathrm{~s}]$ とした。

この結果を見ると, 空気処理の時とは違い，僅か $5 \mathrm{~s}$ の処 理でリモート表面改質効果が現れ始め, 処理時間 $60 \mathrm{~s}$ ではリ モート表面改質効果が飽和していることが分かる。この様 に処理効果が飽和にいたる時間は電極からの距離に異なっ ているが,これを分かりやすくまとめたものが図 13 である。 図 13 は電極からの距離 $0,50, \quad 100[\mathrm{~mm}]$ の地点に的を絞 り, 処理時間の変化に伴う表面改質効果の進展具合をグラ フ化したものである。この結果から, 直接処理領域 $(0 \mathrm{~mm}$ 地点）の $10 \mathrm{~s}, 50 \mathrm{~mm}$ 地点では $30 \mathrm{~s}, 100 \mathrm{~mm}$ 地点では $50 \mathrm{~s}$ の 処理時間が十分な処理効果（これを飽和処理効果と呼ぶこ とにする）を得るために必要であることが分かる。

〈4·4〉処理時間と放電電力の比の影響 これまでの 実験の結果，窒素処理では空気処理の時と異なり，放電電 力の影響があまりないことが明らかになった。一方で，処 理時間の影響が処理性能に大きく影響することも明らかと なった。そこで放電電力と処理時間の影響をより明確に分

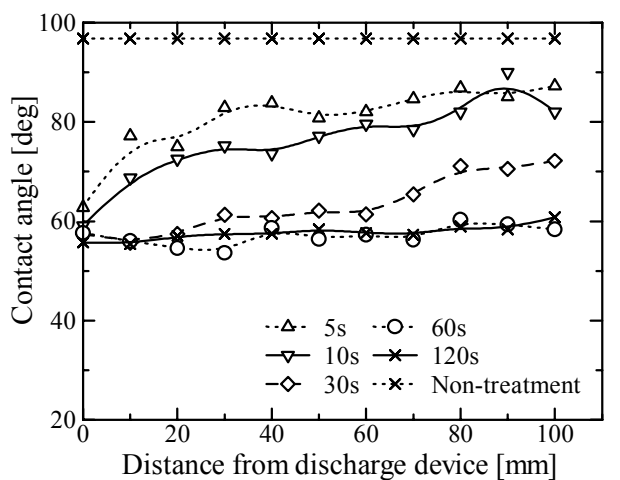

図 12 処理時間のちがいによるリモート表面改質 効果の変化

Fig. 12. Treatment time vs. contact angle in nitrogen.

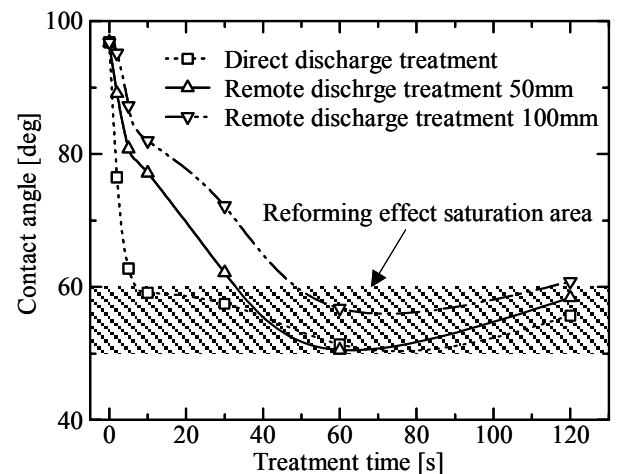

図 13 電極からの距離による表面改質効果飽和時間の違い

Fig. 13. Difference of processing effect saturation time by distance change from electrode in nitrogen.

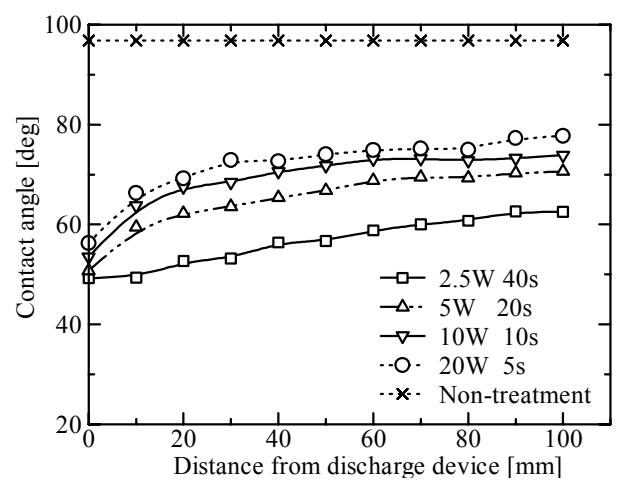

図 14 放電電力と処理時間の影響

Fig. 14. Effect of discharge power and treatment time.

かるようにするため，一定の放電電力量下で処理時間と放 電電力の比を変えた実験を行った。

図 14 にその実験結果を示す。処理条件を周波数 $600 \mathrm{~Hz}$, ガス流速 $5 \mathrm{~m} / \mathrm{s}$, 放電電力量が $100 \mathrm{~J}$ となるように放電電力と

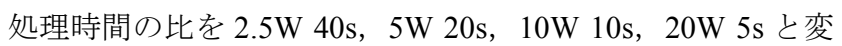
化させた。

この結果を見ると, 窒素処理では小さな放電電力でも良 いので処理時間を長くした方が処理性能に優れることが分 かる。この放電電力の必要最低限の量は放電の安定する程 


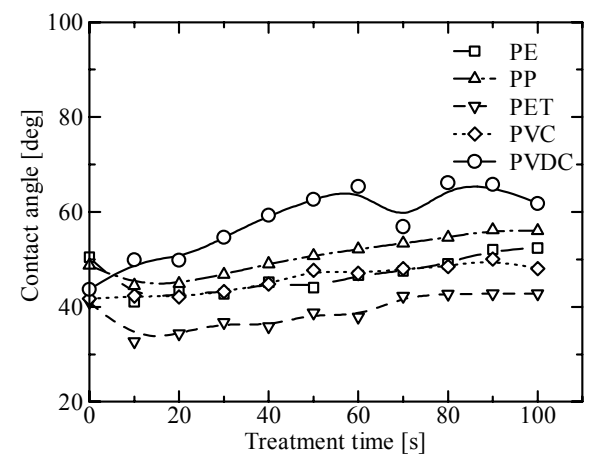

図 15 様々な材質に対するリモート表面改質効果

Fig. 15. A remote surface modification effect for various materials.

表 1 素材毎の初期接触角

Table 1. Initial contact angle.

\begin{tabular}{|c|c|c|c|c|}
\hline PE & PP & PET & PVC & PVDC \\
\hline 96.8 & 99.2 & 82.9 & 88.9 & 79.2 \\
\hline
\end{tabular}

度で良いと考えられる。

\section{5. 様々な材質に対する窒素処理効果}

これまでの検討では表面改質の対象物としてポリエチレ ンフィルムを使用し, 窒素処理がリモート表面改質効果向 上に非常に有効であることが明らかとなってきた。そこで, 材質として，ポリエチレンフィルム以外のプラスチック材 に対しても窒素処理が有効であるか調べる。改質物として, PP(Polypropylene), PET(Polyethylene terephthalate), PVC (Polyvinyl chloride), PVDC(Polyvinylidene chloride)を準備し た。

図 15 に 5 種類のプラスチック材に対して窒素処理を施し た結果を示す。処理条件はガス流速 $5 \mathrm{~m} / \mathrm{s}$, 処理時間 $60 \mathrm{~s}$, 雾 囲気ガスを窒素，放電電力 $5 \mathrm{~W}$ ，周波数を $600[\mathrm{~Hz}]$ とした。 また，各材質の初期接触角を表 1 に示す。

この結果を見ると，材質により多少の違いがあるものの， 全体的に窒素処理により遠方にまで表面改質効果が得られ ていることが分かる。

\section{6. まとめ}

バリア放電を用いたプラスチックの表面改質法として安 定性や処理装置の自由度が高くなるリモート法を取上げ, 放電条件，ガス条件などによる表面改質効果を調べた結果， 以下のことが明らかとなった。

(1) リモートプラズマ処理の改質距離拡大, 改質効果向 上には窒素ガスの使用が非常に有効である。これに対し， 空気を用いたリモート表面改質では大幅なリモート表面改 質効果を得ることは困難である。

（2）雰囲気ガスに窒素を使用したリモート処理法では, 電極から $100 \mathrm{~mm}$ 離れた地点でも直接表面改質と同程度の処 理性能を得られることが分かる。

（3）処理する際の放電電力量 $[\mathrm{J}]$ を一定とした場合, 大き
い放電電力で短時間の処理を施すより小さい電力で長い時 間処理を施した方がリモート表面改質効果は高い。

（4）ガスの種類によらず，ガス流速を速くすることや処 理時間を長くすること, 或いは放電電力を増加することで リモート表面改質効果は向上する。

（5）一定放電電力下で周波数を変化させてもリモート 表面改質効果に違いは生じない。

（6）これらの処理特性は多くのプラスチック材で得ら れる可能性が高い。今回, 窒素処理による表面改質を試し た材質は PE(Polyethylene), PP(Polypropylene), PET (Polyethylene terephthalate), PVC(Polyvinyl chloride), PVDC (Polyvinylidene chloride)である。

(平成 18 年 5 月 19 日受付, 平成 18 年 11 月 10 日再受付)

\section{文献}

(1) S. Takayama, S. Ono, and N. Teii : "Surface Treatment of Plastics by an Atmospheric Pressure Corona Torch", T. IEE Japan, Vol.112-A, No.8, pp.722-727 (2002-8) (in Japanese)

高山史奈子・小野 茂・堤井信力:「大気圧コロナトーチによるプラ スチック表面改質」, 電学論 A, 122, 8, pp.722-727 (2002-8)

( 2 ) M. Soma, T. ueda, K. Yamazaki, Y. Sawada, Y. Nakazono, and Y. Inoue : "Improvement of Adheision Characteristics Using Atmospheric-Pressure Plasma Processing", Matsushita Electric Works. Ltd. Report, pp.61-66 (2002-11) (in Japanese)

相馬 誠・上田友彦・山崎圭一・澤田康志・中園佳幸・井上吉民：「大 気圧プラズマ処理による接着性の向上」, 松下電工技報, pp.61-66 (2002-11)

(3) 小駒益弘 : 「大気圧グロープラズマ法を応用した表面処理」, コンバ ーテック, No.2005-4, pp.95-99 (2005)

（4）小駒益弘：「大気圧グロープラズマ法を応用した表面処理」, コンバ ーテック, No.2005-3, pp.66-69 (2005)

（5）淺野間将太・渡辺 毅・坂井勇一・原田信弘：「誘電体バリア放電プ ラズマによる基盤洗浄実験」, 電気学会プラズマ研資, PST-04-109 (2004)

(6) Y. Yanagisawa and Y. Yoshioka : "Effects of reforming object temperature on the remote surface modification of a PE film by atmosphere pressure $\mathrm{N}_{2}$ barrier discharge", 2006 National Convention Record, IEE Japan, No.1-065, pp.81-82 (2006) (Japanese) 柳沢雄太・吉岡芳夫 : 「大気圧 $\mathrm{N} 2$ バリア放電による PE フィルムの リモート表面改質における改質物温度の影響」, 平成 18 年電気学会 全国大会, No.1-065, pp.81-82 (2006)
柳 沢 雄 太

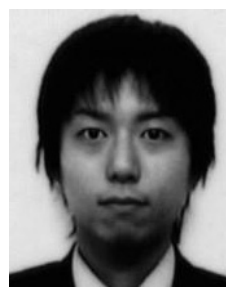

吉岡 芳 夫

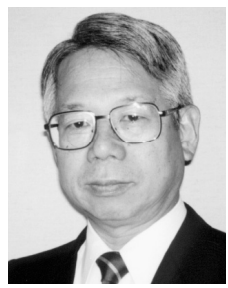

（学生員） 1982 年 5 月 25 日生。 2005 年 3 月金 沢工業大学電気工学部卒業。2007 年 3 月金沢 工業大学大学院修士課程電気電子工学専攻修 了。2007 年 4 月（株）日立製作所入社。現在, バリア放電を用いたプラスチックの表面改質 の研究を実施。
大阪大学理学部物理学科卒業。(株) 日立製作 所を経て, 1998 年 4 月から金沢工業大学電気系 教授。主として, 非熱平衡プラズマによる NOx 除去法, 遮断器の設計法を研究中。工学博士。 技術士 (電気電子部門)。静電気学会, 放電学 会, IEEE，日本工学教育協会会員。 